Article

\title{
Association of Dietary Calcium Intake with Dental, Skeletal and Non-Skeletal Fluorosis among Women in the Ethiopian Rift Valley
}

\author{
Demmelash Mulualem $^{1}$, Dejene Hailu ${ }^{2} \mathbb{D}$, Masresha Tessema $^{3}$ (D) and Susan Joyce Whiting ${ }^{4, *}$ (D) \\ 1 School of Human Nutrition and Food Science, Hawassa University, Hawassa P.O. Box 5, Ethiopia; \\ solymico27@gmail.com \\ 2 School of Public Health, Hawassa University, Hawassa P.O. Box 5, Ethiopia; dejenkassa@yahoo.com \\ 3 Ethiopian Public Health Institute, Addis Ababa 1242, Ethiopia; masresha88@gmail.com \\ 4 College of Pharmacy and Nutrition, University of Saskatchewan, Saskatoon, SK S7N 5E5, Canada \\ * Correspondence: susan.whiting@usask.ca
}

check for

updates

Citation: Mulualem, D.; Hailu, D.;

Tessema, M.; Whiting, S.J.

Association of Dietary Calcium

Intake with Dental, Skeletal and

Non-Skeletal Fluorosis among

Women in the Ethiopian Rift Valley.

Int. J. Environ. Res. Public Health 2022,

19, 2119. https://doi.org/10.3390/

ijerph19042119

Academic Editor: Lauri O. Byerley

Received: 29 December 2021

Accepted: 8 February 2022

Published: 14 February 2022

Publisher's Note: MDPI stays neutral with regard to jurisdictional claims in published maps and institutional affiliations.

Copyright: () 2022 by the authors. Licensee MDPI, Basel, Switzerland. This article is an open access article distributed under the terms and conditions of the Creative Commons Attribution (CC BY) license (https:// creativecommons.org/licenses/by/ $4.0 /)$.

\begin{abstract}
Fluorosis is a major public health problem in the Rift Valley of Ethiopia. Low calcium (Ca) intake may worsen fluorosis symptoms. We assessed the occurrence of fluorosis symptoms among women living in high-fluoride $(\mathrm{F})$ communities in South Ethiopia and their associations with dietary Ca intake. Women $(n=270)$ from two villages provided clinical and questionnaire data. Dental fluorosis examination was done using Dean's Index, and skeletal and non-skeletal fluorosis assessment was carried out using physical tests and clinical symptoms. Daily Ca intake was estimated by a food frequency questionnaire. Food, drinking water and beverage samples were analyzed for F level. Many subjects (56.3\%) exhibited dental fluorosis. One-third of the women were unable to perform the physical exercises indicative of skeletal fluorosis; about half had $\geq 2$ symptoms of skeletal/non-skeletal fluorosis. The average $\mathrm{F}$ level in drinking water sources was $\sim 5 \mathrm{mg} / \mathrm{L}$. The F content in staple food samples varied from $0.8-13.6 \mathrm{mg} / \mathrm{kg}$. Average Ca intake was $406 \pm 97 \mathrm{mg} /$ day. Women having $\leq 400 \mathrm{mg} /$ day Ca intake had $\sim 3$ times greater odds of developing skeletal rigidity with joint pains $[\mathrm{AOR}=2.8,95 \% \mathrm{CI}: 1.6,5.0]$ and muscular weakness $[\mathrm{AOR}=2.9,95 \% \mathrm{CI}: 1.3,6.3]$ compared to those with higher intakes. No association of calcium intake was seen with dental fluorosis. As low dietary Ca intake was associated with symptoms related to skeletal and non-skeletal fluorosis, this warrants nutritional intervention on calcium intakes in this setting.
\end{abstract}

Keywords: calcium intake; fluoride; dental fluorosis; skeletal fluorosis; non-skeletal fluorosis; Ethiopian Rift Valley

\section{Introduction}

Drinking water sources in the Rift Valley of Ethiopia contain fluoride (F) levels exceeding the World Health Organization (WHO) limit of $1.5 \mathrm{mg} / \mathrm{L}[1,2]$. As a consequence, many people living in the region are severely affected by fluorosis [2-8]. In serious cases, dental fluorosis is manifested as brown mottling of the enamel and results in overall yellowing of the teeth with erosion of the enamel [2,8]. Skeletal fluorosis occurs when there is a high degree of bone brittleness due to excess deposition of $\mathrm{F}$ in bone that leads to osteosclerosis [3,6,9-12]. Non-skeletal fluorosis includes muscle weakness manifestations, such as stiffness of the back and neck muscles and pain leading to inability to carry out routine domestic activities [2,9].

Fluorosis is a major public health concern particularly for developing countries including Ethiopia, as the infrastructure needed to remove the excess F ions is lacking or not widely accepted [13,14]. It can affect both children and adults [13]. Over 85\% of Ethiopians living in the Rift Valley have been exposed to excess levels of F intake $[7,15,16]$. Although drinking water is the dominant pathway of F exposure in Ethiopian Rift Valley areas, food 
stuffs prepared with high-F cooking water is also an additional pathway [17]. Foods added an average of 2.3 to $4.8 \mathrm{mg} / \mathrm{kg}$ F depending on village location and type of foods consumed, both plant and animal foods are locally grown in this high-F environment $[2,17]$.

Epidemiological studies of communities with similar F exposures have shown a relationship between calcium $(\mathrm{Ca})$ intake and reduction in severity of dental fluorosis [2,17-19]. The Ca binds with F forming an insoluble Ca fluoride complex in the gastrointestinal tract, preventing absorption and reducing the extent of F exposure [20]. In this way the adverse effects of $\mathrm{F}$ are decreased. Two animal studies have shown that proof of principle [20,21]. To our knowledge, only one study has reported an inverse association between dietary $\mathrm{Ca}$ (milk) and severity of dental fluorosis in individuals in Ethiopia [4] and no one has reported the association between $\mathrm{Ca}$ intake and the severity of skeletal and non-skeletal fluorosis.

In many areas of Ethiopia, dietary Ca intake, particularly of child-bearing women, is well below the recommended dietary allowance [22,23]. F exposure may be an added concern for women's bone and dental health where there is low Ca intake. Therefore, the purpose of this study was to assess the dental, skeletal and non-skeletal fluorosis symptoms and associations with dietary $\mathrm{Ca}$ intake among women of child-bearing age in the Ethiopian Rift Valley.

\section{Materials and Methods}

\subsection{Study Design}

A community-based cross-sectional study design was conducted in two purposively selected kebeles (small administrative divisions of a district, also called villages). The women included in this cross-sectional study were eligible for a planned pilot trial on eggshell supplementation [23] as a Ca source to mitigate fluorosis symptoms [20,21]. The kebeles were known for having fluorosis problems [2].

\subsection{Setting}

The two kebeles included were situated in Halaba district which is located in the main Rift Valley of Southern Ethiopia. The selected two kebeles were known for using drinking water sources with high levels of fluoride content [2]. Halaba is situated $1800 \mathrm{~m}$ above sea level and has low average annual rainfall $(750 \mathrm{~mm})$, which is the major limiting factor of agricultural production. The district is one of the districts in southern Ethiopia where drought often occurs.

\subsection{Inclusion and Exclusion Criteria}

The participant inclusion criteria were being biological mothers of young children (6-18 months) who were subjects of a parallel study, as well as being permanent residents in the selected kebeles. Mothers were excluded if they were taking drugs for any type of illness, had any apparent signs and symptoms of fever and cough at the time of enrollment and those enrolled in any health and nutritional intervention program.

\subsection{Sample Size and Sampling}

The sample size was estimated using EpiInfo Version 7.0.8.3 for descriptive studies by considering $12 \%$ prevalence of clinical symptoms of skeletal and non-skeletal fluorosis among school-age children in the same study area [2], 95\% level of confidence, an absolute precision, $(\mathrm{d}=5 \%)$ and a design effect of 1.5 (to account for cluster sampling). Finally, based on the above assumptions and considering $10 \%$ non-response rate, a minimum sample size of 270 mothers were recruited to determine the level of skeletal and non-skeletal fluorosis among women.

A list of mothers of young children aged 6-18 months old was obtained from the kebeles health post. Using this list, a house-to-house registration was conducted by giving an exclusive code number for each household, and a total of 301 eligible participants were identified in the two kebeles. Finally, a total of 270 eligible women were included in this study. 


\subsection{Variables, Data Collection and Measurements}

The dependent variables for this study were dental, skeletal and non-skeletal fluorosis symptoms. The main exposure variable was dietary $\mathrm{Ca}$ intake. Other predictor variables included: age, educational status, occupation, income, parity, diet diversity, drinking water source, water treatment, family size and years of residency. Data on socio-demographic and economic characteristics, water supply, hygiene and environmental sanitation and obstetric history of mothers were collected using a semi-structured questionnaire that was translated to Hallabigna, the language of the district. The interview was conducted face to face with the selected women by trained data collectors.

\subsection{Dietary Measures}

We collected data on specific foods consumed by women in the previous $24 \mathrm{~h}$ using a structured questionnaire in order to determine the dietary diversity score. The recall was repeated on $10 \%$ of women to determine if these recalls were similar when conducted on different days of the week. In order to determine an individual dietary diversity score, foods were placed into each of ten food groups. Women who consumed five or more food groups in that day were considered to have fulfilled the minimum dietary diversity [24].

A structured food frequency questionnaire was used to assess the usual dietary Ca intake of mothers by asking the daily and weekly frequencies of consumption of specific Ca-rich foods common in this district (milk, yogurt, millet, fruits, kale, other vegetables and moringa). Portion size estimation was made by providing bowls and plates to each mother to help them visualize and serve the amount of each food consumed. These frequencies were converted to daily dietary Ca intakes, as described by Gozdzik et al. [25] using published Ethiopian values for Ca content [26], and recipes were used to identify the amount of $\mathrm{Ca}$ in high-Ca foods, such as millet injera [27]. The assumptions used to convert frequencies of consumption to daily dietary $\mathrm{Ca}$ intake included: if the frequency of consumption of a particular food more than once a day assumed to be twice a day; if once per day, assumed to be once a day; if more than once per week (i.e., 3.5 days on average, thus, $3.5 / 7=0.5)$, so assumed as to be 0.5 times per day; if once per week $(1 / 7=0.15)$, so assumed as to be 0.15 times per day; if once per month $(1 / 30=0.033)$, so assumed as to be 0.033 times per day; and if not consumed over that month, assumed as not consumed daily during that monthly period [25].

\subsection{Determination of Dental, Skeletal and Non-Skeletal Fluorosis}

The women were assessed for dental fluorosis using Dean's index [28] which classifies fluorosis on a scale of 0 to 4 as: Class 0, No Fluorosis; Class 1, Very Mild Fluorosis (opaque white areas irregularly covering 25\% of the tooth surface); Class 2, Mild Fluorosis (white areas covering 25-50\% of the tooth surface); Class 3, Moderate Fluorosis (all surfaces affected, with some brown spots and marked wear on surfaces subject to attrition); and Class 4: Severe Fluorosis (widespread brown stains and pitting). The average score of the two most severely affected teeth was used to derive this classification. The women were instructed to thoroughly clean their teeth prior to the dental fluorosis examination. The dental assessment was conducted by an experienced dentist (MD and DDS degrees) who was hired for this purpose.

Skeletal and non-skeletal fluorosis were determined using clinical symptoms and physical exercises as developed by Susheela [29] and Shashi et al. [12] and as described by Kebede et al. [2]. Individuals who could not perform the physical exercises were categorized as having skeletal fluorosis [12]. The assessment was carried out by an experienced physiotherapist (MSc degree) who was hired to perform the physical examination. All study women were asked to perform three physical exercises which indicate skeletal fluorosis [2]: (i) bending the body and touching floor or toe; (ii) touching chest with chin; and (iii) folding arms to touch back of head. The physiotherapist showed each mother how to perform the exercise. The same physiotherapist assessed the women for the presence or 
absence of thirteen symptoms of skeletal and non-skeletal fluorosis which are itemized below in the Results section (Table 5).

\subsection{Food and Water Sample Collection and Analysis}

The food samples were dried, grounded and homogenized using drying oven, miller and homogenizer respectively for $\mathrm{F}$ analysis. Aliquots of $5 \mathrm{~mL}$ were taken out for analysis after the ash had settled and the solutions were clear. Care was taken to avoid the settled ash. Before analyzing, $0.5 \mathrm{~mL}$ TISABIII was added to obtain a $\mathrm{pH}$ of 5.2-5.4, which is the optimal $\mathrm{pH}$-range for $\mathrm{F}$ determination. Reagent blanks were always prepared together with the samples and were brought through the whole procedure. The F level of standard solutions and sample solutions were measured in ppm using an F ion-selective electrode. For all food samples, $1 \mathrm{~mL}$ of $100 \mathrm{ppm} F$ standard was spiked to determine percent recovery. Water F was determined by using ES ISO 10359-1: 2001 method, whereas food F level was measured by food $\mathrm{F}$ test method [17]. The electrode was calibrated by working standards starting from most diluted to concentrated standard. The concentrations of the solutions were directly measured in ppm by using an $\mathrm{F}$ ion-selective electrode.

\subsection{Bias, and Data Management}

Effort was made to address possible potential sources of information bias. After setting exclusion criteria, we included all eligible women. In order to minimize information bias, the dental, skeletal and non-skeletal fluorosis assessment was conducted by a qualified dentist and physiotherapist who were hired for this purpose. These specialists used pre-defined and validated assessment tools to arrive at a presumptive diagnosis of the condition.

All quantitative data were double-entered in to EpiData version 3.1, and then exported into SPSS version 25 for analyses. All continuous data were checked for normal distribution using the Kolmogorov-Smirnov Test of Normality. Collinearity was checked using variance inflation factor $(<10)$ and tolerance $(>0.1)$, and there was no multicollinearity between the independent variables [30].

\subsection{Fluorosis Symptom Indices}

Data on skeletal and non-skeletal fluorosis symptoms were categorized into three symptom indices according to Tandon et al. [9]. Index-1 is named skeletal rigidity and joint pain, Index-2 is named muscular weakness manifestations and Index-3 is named gastro-intestinal complaints. Index-1 included: skeletal rigidities and pain of the neck region, back, knee and shoulder joints. Index-2 included: stiffness of the back and neck muscles, unable to bend forward and to stand straight and inability to carry out routine activities. Index-3 included: early signs of F toxicity, such as loss of appetite, nausea, pain in the stomach, constipation and gas formation in the stomach with a bloated feeling. When a woman complained of $\geq 2$ symptoms of these types of skeletal and non-skeletal fluorosis symptoms, she was assigned a score of 1 and if not, scored 0 . This was carried out for each fluorosis index. Data on dental fluorosis were analyzed as $1=$ having any level of dental fluorosis severity (very mild through severe) and $0=$ if questionable or normal. The dichotomized value for each index as well as for dental fluorosis was used in the regression analysis.

\subsection{Statistical Methods}

Descriptive statistics, such as mean and frequency, were used to display study results. Logistic regression analysis was conducted to identify factors that could be associated with fluorosis symptoms. The factors were first included in bivariable logistic regression models to check their association with fluorosis symptoms indices. The variables were included in multivariable logistic regression analysis if $p<0.2$. The variables included in the multivariable logistic regression model were age of women, educational status, occupation, parity, DDS, dietary Ca intake, family size and years of residency. 


\subsection{Ethics and Informed Consent}

This study was conducted according to the guidelines laid down in the Declaration of Helsinki and all procedures involving research study participants were approved by Hawassa University College of Medicine and Health Science (Ref. No: IRB/019/10) and University of Saskatchewan Biomedical Research Ethics, Saskatoon, Canada (Ref. No: Bio\# 17-150). After the purpose and methods of the study were fully explained, and their right to refuse was explained, informed verbal and written consents were obtained from all study participants prior to their participation in the study.

\section{Results}

\subsection{Socio-Demographic and Economic Characteristics}

The mean (SD) age of the women in completed years was $29.5 \pm 4.2$ years. Most of the women $(96.5 \%)$ were married, the majority $(67.4 \%)$ had not attended school (were illiterate) and just more than half $(51.9 \%)$ of them had no paid job outside their home. The main source of income for most $(87.8 \%)$ of the households was agriculture and the majority $(82.2 \%)$ of them earned an average of less than 1000 ETB birr per month ( \$20 USD). The average family size (parents and children) was approximately $7 \pm 2$ (Table 1 ).

Table 1. Socio-demographic and economic characteristics of study participants in Halaba district, southern Ethiopian Rift Valley, 2018.

\begin{tabular}{|c|c|c|c|}
\hline \multicolumn{2}{|c|}{ Characteristics $(n=270)$} & $N$ & $(\%)$ \\
\hline \multirow{4}{*}{$\begin{array}{l}\text { Mother's educational } \\
\text { status }\end{array}$} & Illiterate (hadn't attended school) & 182 & 67.4 \\
\hline & Primary education (1st to 8 th grade) & 74 & 27.4 \\
\hline & Secondary education (9th to 12 th grade) & 11 & 4.1 \\
\hline & College (above 12th grade) & 3 & 1.1 \\
\hline \multirow{4}{*}{$\begin{array}{l}\text { Mother's main } \\
\text { occupation }\end{array}$} & No outside job/housewife/ & 140 & 51.9 \\
\hline & Agriculture & 96 & 35.6 \\
\hline & Petty trading & 29 & 10.7 \\
\hline & Employed & 5 & 1.9 \\
\hline \multirow{3}{*}{$\begin{array}{l}\text { Main source of } \\
\text { household income }\end{array}$} & Agriculture & 237 & 87.8 \\
\hline & Petty trading & 24 & 8.9 \\
\hline & Employed & 9 & 3.3 \\
\hline \multirow{5}{*}{$\begin{array}{l}\text { Estimated average } \\
\text { monthly income of } \\
\text { the household } \\
\text { (ETB) }{ }^{1}\end{array}$} & $<500$ & 115 & 42.6 \\
\hline & $501-1000$ & 107 & 39.6 \\
\hline & $1001-1500$ & 26 & 9.6 \\
\hline & $1501-2000$ & 9 & 3.3 \\
\hline & $>2000$ & 13 & 4.8 \\
\hline \multirow{4}{*}{ Residency } & >15 years & 138 & 51.1 \\
\hline & $11-15$ years & 46 & 17.0 \\
\hline & 5-10 years & 62 & 23.0 \\
\hline & $<5$ years & 24 & 8.9 \\
\hline
\end{tabular}

${ }^{1}$ ETB $=$ Ethiopian birr. 1 ETB $=\$ 0.02$ USD in 2018 .

\subsection{Water Supply, Hygiene and Environmental Sanitation}

The main source of drinking water for all households was a tap at a common public pipe, and the majority (63.7\%) of the study participants walked about an hour to get the drinking water from the public pipe. Most of the study participants $(82.2 \%)$ were not filtrating or treating the water before drinking it. Pit latrine was available in most $(88.5 \%)$ households among the study women and most (89.3\%) of them used a bar of soap while washing their hands (Table 2). 
Table 2. Water, hygiene and environmental sanitation of study participants in Halaba district, southern Ethiopian Rift Valley, 2018.

\begin{tabular}{|c|c|c|c|}
\hline \multicolumn{2}{|c|}{ Characteristics $(n=270)$} & \multirow{2}{*}{$\begin{array}{c}N \\
172\end{array}$} & \multirow{2}{*}{$\begin{array}{c}\% \\
63.7\end{array}$} \\
\hline Time to bring water from & $1 \mathrm{~h}$ or less & & \\
\hline public pipe & $>1 \mathrm{~h}$ & 98 & 36.3 \\
\hline \multirow{2}{*}{$\begin{array}{l}\text { Equipment used to store } \\
\text { drinking water }\end{array}$} & Jerrican & 215 & 79.6 \\
\hline & Bucket & 55 & 20.4 \\
\hline \multirow{2}{*}{$\begin{array}{l}\text { Filtrating/treating the water } \\
\text { before drinking }\end{array}$} & No & 222 & 82.2 \\
\hline & Yes & 48 & 17.8 \\
\hline \multirow{3}{*}{$\begin{array}{l}\text { If yes, method of filtration } \\
(n=48)\end{array}$} & Water treatment pills & 29 & 60.4 \\
\hline & Filtering cloths & 17 & 35.4 \\
\hline & $\begin{array}{r}\text { Boiling and removing } \\
\text { sediment }\end{array}$ & 2 & 4.2 \\
\hline \multirow{2}{*}{$\begin{array}{l}\text { Use same water source for } \\
\text { drinking and cooking }\end{array}$} & No & 230 & 85.2 \\
\hline & Yes & 40 & 14.8 \\
\hline \multirow{2}{*}{$\begin{array}{l}\text { Use same water source for } \\
\text { drinking and bathing }\end{array}$} & No & 220 & 81.5 \\
\hline & Yes & 50 & 18.5 \\
\hline \multirow{4}{*}{$\begin{array}{l}\text { Knowledge on hand washing } \\
\text { (affirmative) }\end{array}$} & Before preparing food & 42 & 15.6 \\
\hline & Before feeding the child & 226 & 83.7 \\
\hline & After using toilet & 215 & 79.6 \\
\hline & $\begin{array}{r}\text { After cleaning child } \\
\text { (defecated) }\end{array}$ & 201 & 74.4 \\
\hline \multirow{3}{*}{$\begin{array}{l}\text { Substance used for hand } \\
\text { washing }\end{array}$} & Soap bar & 241 & 89.3 \\
\hline & Just only water & 20 & 7.4 \\
\hline & Liquid soap & 9 & 3.3 \\
\hline \multirow{3}{*}{ Household latrine type } & Outside home latrine & 239 & 88.5 \\
\hline & Protected open field & 20 & 7.4 \\
\hline & No latrine (open field) & 11 & 4.1 \\
\hline
\end{tabular}

There was no attempt by study participants or health workers in these kebeles to take any measure (including dietary) to lessen the toxic effects of excess F intake. Study participants also did not receive health education about excess intake of $\mathrm{F}$ in foods or drinks, its consequences on health (fluorosis) and measures needed to be taken to reduce $\mathrm{F}$ exposure, prior to this study. None of the households used rainwater for drinking as it was scarce and due to fearing of dusts contamination from the roof. Bed nets were available in less than half (44.4\%) of the study participants' households.

\subsection{Obstetric History of Women}

Regarding the history of childbirth of the women, $23.3 \%$ of mothers had a history of spontaneous abortion (i.e., miscarriage) and $15.2 \%$ had a history of stillbirth. The average of live-born children by the study mothers was approximately four (data not shown).

\subsection{Fluoride Level in Food, Beverage and Water Samples}

The F content in staple food samples varied between $0.8-13.6 \mathrm{mg} / \mathrm{kg}$. The foods which were prepared from maize and millet had higher $F$ levels, whereas vegetable food sources, such as cabbage and potato had low concentration of F. For all food items, percent recovery varied between $90.4-107.9 \%$, which falls on the acceptable range of percent recovery. All common drinking water sources in the study area had an F level exceeding the WHO guidelines for drinking water $(1.5 \mathrm{mg} / \mathrm{L})$. The average $\mathrm{F}$ level in drinking water sources was approximately $5 \mathrm{mg} / \mathrm{L}$ (Table 3 ). 
Table 3. Fluoride level in staple foods, beverage and drinking water consumed by the study subjects in Halaba district, southern Ethiopian Rift Valley, 2018.

\begin{tabular}{lcc}
\hline Sample Type & Fluoride & Recovery (\%) \\
\hline \multicolumn{1}{c}{ Food } & $\mathrm{mg} / \mathrm{kg}$ & 100.6 \\
Injera (unknown ingredients) & 10.6 & 97.2 \\
Unleavened bread (unknown ingredients) & 13.6 & 102.5 \\
Unleavened bread, maize & 12.5 & 96.2 \\
Taro, Colacasia antiquorum:, boiled & 4.6 & 102.5 \\
Injera (Maize, Millet (1:1)) & 8.3 & 93.7 \\
Unleavened bread, millet & 4.9 & 103.2 \\
Boiled cabbage & 0.8 & 92.2 \\
Boiled potato and carrot & 1.6 & 103.6 \\
Stew without tomato & 3.9 & 107.9 \\
Banana & 5.3 & 102.7 \\
Boiled beetroot & 3.2 & 95.9 \\
Cabbage and potato stew & 2.4 & 103.6 \\
Rice with carrot & 3.2 & 95.4 \\
Injera (sorghum, maize, millet (1:1:1)) & 4.9 & 105.7 \\
Injera (millet) & 7.8 & 99.0 \\
Bread (maize) & 10.5 & \\
& $\mathrm{mg} / \mathrm{kg}$ & 104.5 \\
Coffee (prepared from coffee leaf) & 3.5 & \\
Drinking water & $\mathrm{mg} / \mathrm{L}$ & \\
Drilled tap water & 4.7 & \\
Hand pump water & 6.2 & \\
Well water & 3.3 & \\
\hline
\end{tabular}

\subsection{Dietary Calcium Intake of Women}

The average daily dietary Ca intake of women was $406 \pm 97 \mathrm{mg}$ (Table 4). Only 37.4\% of women consumed one or more locally available Ca-rich foods daily. More than half $(55.2 \%)$ of the women also did not consume yogurt and approximately one-quarter $(23.3 \%)$ did not drink milk during the last month prior to this survey. No participant reported consuming moringa. The mean (SD) dietary diversity score of women based on 10 food groups was (mean (SD)) 4.92 (1.91).

Table 4. Frequency of calcium-rich food consumption by women in Halaba district, southern Ethiopian Rift Valley, 2018.

\begin{tabular}{|c|c|c|c|c|c|c|c|}
\hline $\begin{array}{l}\text { Frequency of } \\
\text { Consumption } \\
\quad(n=270)\end{array}$ & $\begin{array}{c}\text { Milk } \\
N(\%)\end{array}$ & $\begin{array}{l}\text { Yogurt } \\
N(\%)\end{array}$ & $\begin{array}{l}\text { Millet } \\
N(\%)\end{array}$ & $\begin{array}{c}\text { Kale } \\
N(\%)\end{array}$ & $\begin{array}{c}\text { Fruits * } \\
N(\%)\end{array}$ & $\begin{array}{c}\text { Other } \\
\text { Vegetables } \# \\
N(\%)\end{array}$ & $\begin{array}{c}\text { Moringa } \\
N(\%)\end{array}$ \\
\hline$>$ Once per day & $29(10.7)$ & $21(7.8)$ & $114(42.2)$ & $125(46.3)$ & $22(8.1)$ & $25(9.3)$ & 0 \\
\hline Once a day & $27(10.0)$ & $19(7.0)$ & $66(24.4)$ & $61(22.6)$ & $9(3.3)$ & $12(4.4)$ & 0 \\
\hline >Once per week & $32(11.9)$ & $15(5.6)$ & $55(20.4)$ & $49(18.1)$ & $39(14.4)$ & $38(14.1)$ & 0 \\
\hline Once a week & $67(24.8)$ & $30(11.1)$ & $26(9.6)$ & $35(13.0)$ & 147 (54.4) & $122(45.2)$ & 0 \\
\hline Once a month & 52 (19.3) & $36(13.3)$ & $9(3.3)$ & 0 & $16(5.9)$ & $25(9.3)$ & 0 \\
\hline Not consumed & $63(23.3)$ & $149(55.2)$ & 0 & 0 & $37(13.3)$ & $48(17.8)$ & $270(100)$ \\
\hline \multicolumn{8}{|c|}{ Daily dietary calcium $(\mathrm{mg}): 406.4 \pm 96.8$} \\
\hline
\end{tabular}

\subsection{Fluorosis Assessment of Women}

Overall, more than half (56.3\%) of the study women had very mild to severe dental fluorosis (Table 5). The percentage of severe dental fluorosis was $9.3 \%$; and the percentage of women with moderate dental fluorosis was $25.2 \%$. 
Table 5. Prevalence $(\%)$ of fluorosis among women $(n=270)$ in Halaba district, southern Ethiopian Rift Valley, 2018.

\begin{tabular}{|c|c|c|}
\hline Measurement & $\mathbf{N}$ & $\%$ \\
\hline \multicolumn{3}{|l|}{ Dental fluorosis category } \\
\hline Normal & 96 & 35.6 \\
\hline Questionable & 22 & 8.1 \\
\hline $\begin{array}{l}\text { Very mild: opaque white areas covering } 25 \% \text { of the tooth } \\
\text { surface }\end{array}$ & 38 & 14.1 \\
\hline Mild: white areas covering $25 \%-50 \%$ of the tooth surface & 21 & 7.8 \\
\hline $\begin{array}{l}\text { Moderate: all surfaces affected, with some brown spots and } \\
\text { marked wear on surfaces subject to attrition }\end{array}$ & 68 & 25.2 \\
\hline Severe: widespread brown stains and pitting & 25 & 9.3 \\
\hline \multicolumn{3}{|l|}{ Skeletal Fluorosis Exercise Testing } \\
\hline Unable to bend body and touch floor or toe & 76 & 28.1 \\
\hline Unable to touch chest with chin & 109 & 40.4 \\
\hline Unable to stretch and fold arms to touch back of head & 94 & 34.8 \\
\hline \multicolumn{3}{|l|}{ Symptoms of Non-skeletal Fluorosis } \\
\hline Feel lower back pain & 191 & 70.7 \\
\hline Feel leg pain, joints & 182 & 67.4 \\
\hline Feel arm pain, joints & 143 & 53.0 \\
\hline Feel tingling in the hands and feet & 172 & 63.7 \\
\hline Feel neck pain with movement & 125 & 46.3 \\
\hline Feel muscle weakness & 148 & 54.8 \\
\hline Feel loss of appetite & 100 & 37.0 \\
\hline Have nausea & 101 & 37.4 \\
\hline Have abdominal pain & 131 & 48.5 \\
\hline Have bloating in stomach & 60 & 22.2 \\
\hline Experience polydipsia (excessive thirst) & 22 & 8.1 \\
\hline Experience polyuria (excess urine volume) & 16 & 5.9 \\
\hline Experience constipation & 214 & 79.3 \\
\hline
\end{tabular}

The overall percentage of women who were unable to perform the physical exercises which indicate skeletal fluorosis was $34.4 \%$. During the skeletal fluorosis examination, $40.4 \%$ of the women were unable to touch chest with chin and $34.8 \%$ of the women were unable to touch back of head by stretching and folding their hands. Overall, $124(45.9 \%)$ of the women complained of more than one symptom listed in Table 5 . The majority of the women felt lower back pain (70.7\%) and had constipation (79.3\%). More than half (54.8\%) of them also had muscle weakness. In addition, around half of the women had neck pain $(46.3 \%)$ or had been complaining of abdominal pain (48.5\%).

\subsection{Association of Fluorosis Indices with Dietary Ca Intake}

As shown in Table 6, we tested the association of skeletal fluorosis with subject characteristics and environmental factors. For skeletal rigidity and joint pains, Index-1, age, diet diversity and dietary Ca intake were significantly associated with having two or more symptoms. For having muscular weakness, Index-2, age, parity and dietary Ca intake were significantly associated, in the adjusted model. For both Index-1 and Index-2, only age and dietary calcium contributed to worsening of this condition. This study revealed that women whose dietary Ca intake was less than $400 \mathrm{mg} /$ day, which was the average intake (Table 4), had about three times greater odds of developing Index-1 skeletal rigidity with joint pains ( $\mathrm{AOR}=2.8,95 \% \mathrm{CI}: 1.6,5.0)$ and muscular weakness, Index-3 (AOR $=2.9$, $95 \%$ CI: 1.3, 6.3), than those who had higher intake. 
Table 6. Factors associated with muscular-skeletal symptoms of fluorosis Index-1 and Index-2 among women: logistic regression model.

\begin{tabular}{|c|c|c|c|c|c|c|c|c|c|}
\hline \multirow{2}{*}{$\begin{array}{l}\text { Variable } \\
(n=270)\end{array}$} & \multirow{2}{*}{ Category } & \multicolumn{2}{|c|}{$\begin{array}{l}\text { Skeletal Rigidity and } \\
\text { Joint Pains Index-1 }\end{array}$} & \multirow{2}{*}{$\begin{array}{c}\text { COR } \\
(95 \% \mathrm{CI})\end{array}$} & \multirow{2}{*}{$\begin{array}{c}\text { AOR } \\
(95 \% \mathrm{CI})\end{array}$} & \multicolumn{2}{|c|}{$\begin{array}{l}\text { Muscular Weakness } \\
\text { Index-2 }\end{array}$} & \multirow{2}{*}{$\begin{array}{c}\text { COR } \\
(95 \% \mathrm{CI})^{\#}\end{array}$} & \multirow{2}{*}{$\begin{array}{c}\text { AOR } \\
(95 \% \mathrm{CI})\end{array}$} \\
\hline & & $\begin{array}{c}\text { No } \\
N(\%)\end{array}$ & $\begin{array}{c}\text { Yes } \\
N(\%)\end{array}$ & & & $\begin{array}{c}\text { No } \\
N(\%)\end{array}$ & $\begin{array}{c}\text { Yes } \\
N(\%)\end{array}$ & & \\
\hline Age (y) & Mean (SD) & \multicolumn{2}{|c|}{$29.5(4.2)$} & $1.2(1.1,1.2)$ & $1.2(1.0,1.2)$ * & \multicolumn{2}{|c|}{$29.5(4.2)$} & $1.8(1.6,2.0)$ & $1.7(1.5,2.0)$ * \\
\hline \multirow[t]{2}{*}{ Education } & $\begin{array}{r}\text { Unable to read and } \\
\text { write }\end{array}$ & 47 (33.8) & $92(66.2)$ & $1.6(0.9,2.5)$ & $1.6(0.9,2.7)$ & $65(46.8)$ & $74(53.2)$ & $1.7(1.0,2.7)$ & $1.2(0.6,2.5)$ \\
\hline & $\begin{array}{r}\text { Able to read and } \\
\text { write }\end{array}$ & $58(44.3)$ & $73(55.7)$ & 1 & & 78 (59.5) & $53(40.5)$ & 1 & \\
\hline \multirow{2}{*}{ Occupation } & No job & $40(39.6)$ & $61(60.4)$ & 1 & & $47(46.5)$ & $54(53.5)$ & 1 & \\
\hline & Have job & $65(38.5)$ & 104 (61.5) & $1.1(0.6,1.7)$ & $1.3(0.8,2.4)$ & $96(56.8)$ & $66(42.3)$ & $1.4(0.9,2.3)$ & $1.5(0.7,3.0)$ \\
\hline \multirow{2}{*}{ Parity } & $\leq 4$ live births & 32 (37.2) & $54(62.8)$ & 1 & & $90(57.7)$ & $66(42.3)$ & 1 & \\
\hline & $>4$ live births & 73 (39.7) & $111(60.3)$ & $1.1(0.7,1.9)$ & $1.2(0.6,2.2)$ & $53(46.5)$ & $61(53.5)$ & $1.6(1.0,2.6)$ & $2.5(1.1,5.6)$ * \\
\hline \multirow{2}{*}{$\begin{array}{l}\text { Family } \\
\text { size }^{\$}\end{array}$} & $\leq 5$ members & $32(45.1)$ & $39(54.9)$ & 1 & \multirow[b]{2}{*}{$1.3(0.7,2.4)$} & $46(64.8)$ & $25(35.2)$ & 1 & \multirow[b]{2}{*}{$1.1(0.4,2.3)$} \\
\hline & $>5$ members & 73 (36.7) & $126(63.3)$ & $1.4(0.8,2.4)$ & & 97(48.7) & $102(51.3)$ & $1.9(1.1,3.4)$ & \\
\hline $\begin{array}{l}\text { Diet } \\
\text { Diversity }\end{array}$ & $\leq 5$ food groups & $53(32.5)$ & $110(67.5)$ & $1.9(1.19,3.2)$ & 2. $0(1.1,3.4)^{*}$ & 81 (49.7) & $82(50.3)$ & $1.4(0.9,2.3)$ & $1.5(0.7,3.0)$ \\
\hline \multirow{2}{*}{$\begin{array}{l}\text { Dietary } \\
\mathrm{Ca}\end{array}$} & $\leq 400 \mathrm{mg} /$ day & 35 (25.4) & 103 (74.6) & $3.3(2.0,5.6)$ & \multirow[t]{2}{*}{$2.8(1.6,5.0)$ * } & $54(39.1)$ & $84(60.9)$ & $3.2(1.9,5.3)$ & \multirow[t]{2}{*}{$2.9(1.3,6.3)$} \\
\hline & $>400 \mathrm{mg} /$ day & $70(53.0)$ & $62(47.0)$ & 1 & & $89(67.4)$ & $43(32.6)$ & 1 & \\
\hline \multirow{2}{*}{ Residency } & $\leq 10$ years & $40(46.5)$ & $46(53.5)$ & 1 & \multirow[b]{2}{*}{$1.1(0.6,2.0)$} & 57 (66.3) & 29 (33.7) & 1 & \multirow[b]{2}{*}{$1.8(0.8,4.0)$} \\
\hline & $>10$ years & $65(35.3)$ & $119(64.7)$ & $1.6(0.9,2.7)$ & & 86 (46.7) & $98(53.3)$ & $2.2(1.3,3.8)$ & \\
\hline
\end{tabular}

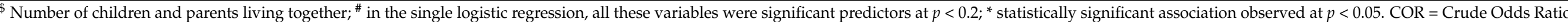
AOR = Adjusted Odds Ratio. 
The odds of developing both Index-1 and Index-2 fluorosis symptoms were 1.2 (95\%CI: $1.0,1.2)$ and 1.7 (95\%CI: $1.5,2.0)$, respectively, with each passing year of age (Table 6). No variables were significantly associated $(p>0.05)$ with either Index-3 (Gastro-intestinal complaints) (Appendix A Table A1) or dental fluorosis (Appendix A Table A2).

\section{Discussion}

More than half of the women in this study had dental fluorosis as diagnosed using Dean's index criteria [28]. This is in line with the findings of a recent systematic review which reported a high prevalence of dental fluorosis in the Ethiopian Rift Valley [7]. In addition, a high prevalence of dental fluorosis was reported among children living in moderate F (24.1\%) and high-fluoride (75.9\%) areas of the Ethiopian Rift Valley [13]. Another study also reported a higher prevalence of dental fluorosis (62\%) among adult inhabitants in the main Rift Valley of Ethiopia [4]. Our data show that women of child-bearing age can be affected by high F, but dental fluorosis develops mainly during early childhood [31]. In contrast with Kravchenko et al. [4], who reported an inverse association with milk intake in young adults living in the Rift Valley, we found no predictors of dental fluorosis. This could be due to the fact that dental fluorosis is an irreversible process that occurred as a result of long-term exposure to excess fluoride during childhood period, and thus was no longer related to current calcium consumption.

Few studies have reported on non-dental fluorosis symptoms in women. We classified symptoms according to skeletal rigidity and pain (skeletal fluorosis), muscular weakness (a major outcome of non-skeletal fluorosis) and gastro-intestinal complaints (other symptoms of non-skeletal fluorosis [9]. Skeletal rigidity accompanied by joint pains was common among women. Muscular weakness manifestations were also observed in many of the women. In addition, early signs of F toxicity, such as gastro-intestinal complaints manifested as loss of appetite, nausea and constipation, were observed in some of the women.

The women in the present study had a low intake of dietary $\mathrm{Ca}$, averaging close to $400 \mathrm{mg}$ per day. This is in agreement with the findings of Tesfaye et al. [22] who assessed national Ca intakes of Ethiopian women in the reproductive age using a single $24 \mathrm{~h}$ dietary recall and found the national average to be $478 \mathrm{mg}$ per day. For women in the same state as our study, the Southern Nations, Nationalities and People Regional state (SNNPR), these authors found average Ca intake of $622 \mathrm{mg}$ per day. In contrast, the Ca intakes of women in this study were estimated from daily and weekly consumption frequencies of Ca-rich foods during a one-month period. Differences may be due to different methodologies or actual differences in our kebeles; however, both sets of results show a lack of adequate dietary $\mathrm{Ca}$ in most women.

In our regression analysis, study mothers who had inadequate Ca intake $(\leq 400 \mathrm{mg} / \mathrm{d})$ had three times increased odds of developing skeletal and non-skeletal fluorosis symptoms, namely skeletal rigidity with joint pains and muscular weakness manifestations, compared with those with higher Ca intake. To our knowledge, no study has been conducted to assess Ca intakes as predictors of skeletal or non-skeletal fluorosis symptoms. Kravchenko and colleagues [4] found a significant correlation between milk intake and dental fluorosis severity among men and women in the Ethiopian Rift Valley. Therefore, milk was the main source of $\mathrm{Ca}$ and presumably measured intake represented usual practice. Not many women in our study ingested dairy products as a source of $\mathrm{Ca}$.

A decrease in $\mathrm{F}$ absorption by dietary $\mathrm{Ca}$ has only been demonstrated in a small number of animal studies [20,21]. In these experiments, $\mathrm{Ca}$ added to the diet reduced urinary F excretion, indicating the gastrointestinal binding of F ions by Ca. Kebede et al. [20] also verified this finding by showing a decrease in fecal F levels. However, most support for the $\mathrm{Ca}$ effect on $\mathrm{F}$ has been shown in observational studies. An earlier epidemiological study of children in India reported greater prevalence of fluorosis symptoms among children with inadequate dietary $\mathrm{Ca}$ intake [18]. In that study, children with adequate dietary $\mathrm{Ca}$ (>800 mg/d) and deficient dietary Ca (<300 mg/d) having comparable intakes of F (mean 
$9.5 \pm 1.9 \mathrm{mg} / \mathrm{d}$ ) were compared; severe toxic effects of $\mathrm{F}$ were observed in children with Ca deficiency [18].

Similarly, our recent efficacy trial provided a proof of concept on calcium intake and fluoride. In this trial, the study subjects were supplemented with an approximate of $1000 \mathrm{mg}$ of calcium (using calcium-containing eggshell powder) on a daily base for six consecutive months. The urinary F excretion in the supplemented group was six-fold lower $(\beta=-6.1$ (95\% CI: $-7.1,-5.1)$ ) compared to the control group. The risk of developing skeletal and non-skeletal fluorosis was also significantly $(p<0.001)$ reduced in the treatment group [23].

Gastrointestinal complaints (Index-3) were not associated with Ca intake, or any other factors related to development of fluorosis, in contrast to skeletal rigidity and pains (Index1) and muscular weakness (Index-2). Assefa et al. [3] used four clinical signs of non-dental fluorosis and compared these to radiological confirmation of skeletal fluorosis in 180 men and 5 women in Ethiopia from a high $\mathrm{F}$ area, mean age 55 years. Skeletal fluorosis was present in $70 \%$ of subjects, while clinical prevalence using kyphosis, impaired squatting, impaired neck mobility and impaired lumbar mobility, averaged $20 \%$. This indicates clinical signs have low sensitivity; however, all signs except kyphosis were in high agreement $(p<0.001)$ with radiological skeletal fluorosis, indicating good specificity.

In the current study, older age was significantly associated with skeletal and nonskeletal fluorosis symptoms. This is in line with the findings of a community-based survey on epidemiology of skeletal fluorosis by Melaku and his colleagues [5]. These authors reported that older people of age 55 years and above had 20 times higher risk of developing skeletal fluorosis than adolescents and young adults of 15 to 24 years of age [5]. This could be due to the fact that in an area where $\mathrm{F}$ intake is higher, more $\mathrm{F}$ would be accumulated in bones and soft tissues of individuals who consumed it throughout their longer lifetime.

Our findings showed that women that have a high parity had greater odds of developing skeletal and non-skeletal fluorosis symptoms compared with those with lower parity. Older women were found to have a greater number of children, and hence parity may reflect the older age of women with more children and additionally, the stress of repeated pregnancy and lactation that may have depleted the Ca stores of these women $[32,33]$. Consequently, fluorosis symptoms would be manifested more among the women with high parity level. Therefore, this finding may have implications for recommendations of Ca during pregnancy and lactation in high-F areas.

The F level in drinking water sources in this area averaged $\sim 5 \mathrm{mg} / \mathrm{L}$ and in staple foods ranged from $0.8-13.6 \mathrm{mg} / \mathrm{kg}$. Similarly, the F level of the drinking water in this area was previously reported as $4.6 \pm 1.7 \mathrm{mg} / \mathrm{L}$ [2]. The primary preferred option may be to find a supply of safe drinking water with safe F levels. In such instances, de-fluoridation may be sought as a solution [34,35]. However, there was no defluoridation of high-F containing water as well as no fluorosis prevention strategies attempted in the current study area. In this area, rainwater, a source of low-F drinking and cooking water, was not used for drinking as it was scarce and due to fearing of dust contamination from the roof of the house when available. Rainwater is not viewed as clean in many parts of the world [36]. In terms of addressing fluorosis symptoms, new technologies may assist, for example, in remineralization of teeth [37].

The limitations of this study include using some non-specific clinical symptoms and physical exercise tests to assess skeletal and non-skeletal fluorosis may be inaccurate and may introduce mis-classification bias. However, we employed the same dentist and physiotherapist to do all measurements, which reduces measurement bias. We also did not include women with only one symptom as being fluorotic to minimize the false positives arising from counting one nonspecific symptom. For skeletal fluorosis, we did not have access to x-ray measurements. We combined symptoms to create unique indices in order to analyze the presence of multiple symptoms. Daily dietary calcium intake of the women was estimated from frequencies of calcium-rich foods consumption which might not have estimated the usual calcium intake of women beyond that month. 


\section{Conclusions}

Signs and symptoms of dental, skeletal and non-skeletal fluorosis were prevalent in women of child-bearing age in this area of the Rift Valley of Ethiopia, where water and food sources of fluoride were high. Dietary calcium intake was low relative to requirements, averaging only $400 \mathrm{mg}$ per day. The low intake of dietary calcium, less than $400 \mathrm{mg}$ per day, was significantly associated with musculo-skeletal fluorosis symptoms but not with nonskeletal fluorosis or dental fluorosis. The presence of musculo-skeletal fluorosis impairs everyday life for the women, who have a very labor-intensive life of raising children and having farm and home responsibilities. This suggests the need for further investigation on improving calcium intakes to mitigate the toxic effects of high fluoride intake in the Ethiopian Rift Valley.

Author Contributions: D.M., M.T. and S.J.W. participated in the conception and design. D.M., D.H., and S.J.W., participated in the analyses of the study. Acquisition of data was by D.M. The first draft of the work was by D.M. All authors revised the manuscript critically for important intellectual content. All authors have read and agreed to the published version of the manuscript.

Funding: This research was funded by Grand Challenges Canada (GCC), grant number R-ST-POC1707-05521. GCC had no role in the design of the study; in the collection, analyses, or interpretation of data; in the writing of the manuscript.

Institutional Review Board Statement: The study was conducted according to the guidelines of the Declaration of Helsinki, and approved by the University of Saskatchewan's Biomedical Research Ethics Board and Hawassa University's Institutional Review Board.

Informed Consent Statement: Informed consent was obtained from all subjects involved in the study.

Data Availability Statement: Data will be made available upon request.

Conflicts of Interest: The authors declare no conflicts of interest. The funders had no role in the design of the study; in the collection, analyses, or interpretation of data; in the writing of the manuscript, or in the decision to publish the results.

\section{Appendix A}

Table A1. Factors associated with non-skeletal symptoms of fluorosis Index-3 among women: a single and multivariable logistic regression model.

\begin{tabular}{|c|c|c|c|c|c|}
\hline \multirow{2}{*}{ Variable $(\mathrm{n}=270)$} & \multirow{2}{*}{ Category } & \multicolumn{2}{|c|}{$\begin{array}{l}\text { Gastro-Intestinal } \\
\text { Complaints Index-3 }\end{array}$} & \multirow{2}{*}{$\operatorname{COR}(95 \% \mathrm{CI})$ \# } & \multirow{2}{*}{ AOR $(95 \% \mathrm{CI})$} \\
\hline & & $\begin{array}{c}\text { No } \\
\text { Number (\%) }\end{array}$ & $\begin{array}{c}\text { Yes } \\
\text { Number (\%) }\end{array}$ & & \\
\hline Age (year) & Mean (SD) & \multicolumn{2}{|c|}{$29.5(4.2)$} & $0.95(0.89,1.01)$ & $0.95(0.88,1.01)$ \\
\hline \multirow[t]{2}{*}{ Education } & $\begin{array}{r}\text { Unable to read and } \\
\text { write }\end{array}$ & $82(59.0)$ & $57(41.0)$ & $1.1(0.69,1.84)$ & $1.2(0.72,2.01)$ \\
\hline & $\begin{array}{r}\text { Able to read and } \\
\text { write }\end{array}$ & $81(61.8)$ & $50(38.2)$ & 1 & \\
\hline \multirow{2}{*}{ Occupation } & No job & 64 (63.4) & 37 (36.6) & 1 & \\
\hline & Have job & $99(58.6)$ & $70(41.4)$ & $1.2(0.74,2.03)$ & $1.2(0.72,2.04)$ \\
\hline \multirow{2}{*}{ Parity } & $\leq 4$ live births & $92(59.0)$ & $64(41.0)$ & 1 & \\
\hline & $>4$ live births & $71(62.3)$ & $43(37.7)$ & $1.2(0.70,1.89)$ & $1.1(0.65,1.91)$ \\
\hline \multirow{2}{*}{ Family size } & $\leq 5$ & $40(56.3)$ & 31 (43.7) & 1 & \\
\hline & $>5$ & $123(61.8)$ & $76(38.2)$ & $1.3(0.72,2.17)$ & $1.3(0.73,2.33)$ \\
\hline
\end{tabular}


Table A1. Cont.

\begin{tabular}{|c|c|c|c|c|c|}
\hline \multirow{2}{*}{ Variable $(n=270)$} & \multirow{2}{*}{ Category } & \multicolumn{2}{|c|}{$\begin{array}{l}\text { Gastro-Intestinal } \\
\text { Complaints Index-3 }\end{array}$} & \multirow{2}{*}{$\operatorname{COR}(95 \% \mathrm{CI}){ }^{\#}$} & \multirow{2}{*}{$\operatorname{AOR}(95 \% \mathrm{CI})$ * } \\
\hline & & $\begin{array}{c}\text { No } \\
\text { Number (\%) }\end{array}$ & $\begin{array}{c}\text { Yes } \\
\text { Number (\%) }\end{array}$ & & \\
\hline \multirow{2}{*}{ Diet Diversity } & $\leq 5$ food groups & 99 (60.7) & $64(39.3)$ & $0.96(0.59,1.58)$ & 1. $0(0.61,1.70)$ \\
\hline & $>5$ food groups & $64(59.8)$ & $43(40.2)$ & 1 & \\
\hline \multirow{2}{*}{ Dietary Ca } & $\leq 400 \mathrm{mg} /$ day & $84(60.9)$ & $54(39.1)$ & $1.1(0.64,1.70)$ & $1.0(0.58,1.74)$ \\
\hline & $>400 \mathrm{mg} /$ day & $79(59.8)$ & $53(40.2)$ & 1 & \\
\hline \multirow{2}{*}{ Residency } & $\leq 10$ years & $56(65.1)$ & $30(34.9)$ & 1 & \\
\hline & $>10$ years & $107(58.2)$ & 77 (41.8) & $1.3(0.79,2.29)$ & $1.5(0.84,2.58)$ \\
\hline
\end{tabular}

\# In the single logistic regression, some of variables were significant predictors at $p<0.2$. ${ }^{*}$ There was no statistical significant association observed for any of the variables at $p>0.05$.

Table A2. Factors associated with dental fluorosis among women: a single and multivariable logistic regression model.

\begin{tabular}{|c|c|c|c|c|c|}
\hline \multirow[b]{2}{*}{ Variable $(n=270)$} & \multirow[b]{2}{*}{ Category } & \multicolumn{2}{|c|}{ Dental Fluorosis ${ }^{1}$} & \multirow{2}{*}{$\begin{array}{c}\text { COR } \\
(95 \% \mathrm{CI})^{2}\end{array}$} & \multirow{2}{*}{$\begin{array}{c}\text { AOR } \\
(95 \% \mathrm{CI})^{3}\end{array}$} \\
\hline & & $\begin{array}{c}\text { Absent } \\
\text { Number (\%) }\end{array}$ & $\begin{array}{c}\text { Present } \\
\text { Number (\%) }\end{array}$ & & \\
\hline Age (year) & Mean (SD) & \multicolumn{2}{|c|}{$29.5(4.2)$} & $1.0(0.96,1.07)$ & $1.0(0.96,1.08)$ \\
\hline \multirow[t]{2}{*}{ Education } & $\begin{array}{l}\text { Unable to read and } \\
\text { write }\end{array}$ & $57(41.0)$ & $82(59.0)$ & $1.3(0.77,2.03)$ & $1.2(0.73,1.99)$ \\
\hline & $\begin{array}{r}\text { Able to read and } \\
\text { write }\end{array}$ & $61(46.6)$ & $70(53.4)$ & 1 & \\
\hline \multirow{2}{*}{ Occupation } & No job & $37(36.6)$ & $64(63.4)$ & 1 & \\
\hline & Have job & $81(47.9)$ & $88(52.1)$ & $1.6(0.96,2.64)$ & $1.6(0.95,2.68)$ \\
\hline \multirow{2}{*}{ Parity } & $\leq 4$ live births & $65(41.7)$ & $91(58.3)$ & 1 & \\
\hline & $>4$ live births & $53(46.5)$ & $61(53.5)$ & $1.2(0.75,1.98)$ & $1.3(0.78,2.02)$ \\
\hline \multirow{2}{*}{ Family } & $\leq 5$ & $32(45.1)$ & $39(54.9)$ & 1 & \\
\hline & $>5$ & $86(43.2)$ & $113(56.8)$ & $1.1(0.63,1.86)$ & $1.0(0.78,2.27)$ \\
\hline \multirow{2}{*}{ Diet Diversity } & $\leq 5$ food groups & $72(44.2)$ & $91(55.8)$ & $1.1(0.64,1.72)$ & 1. $0(0.60,1.66)$ \\
\hline & $>5$ food groups & $46(43.0)$ & $61(57.0)$ & 1 & \\
\hline \multirow{2}{*}{ Dietary Ca } & $\leq 400 \mathrm{mg} /$ day & $61(44.2)$ & $77(55.8)$ & $1.0(0.64,1.69)$ & $1.3(0.76,2.24)$ \\
\hline & $>400 \mathrm{mg} /$ day & $57(43.2)$ & $75(56.8)$ & 1 & \\
\hline \multirow{2}{*}{ Residency } & $\leq 10$ years & $40(46.5)$ & $46(53.5)$ & 1 & \\
\hline & $>10$ years & $78(42.4)$ & $106(57.6)$ & $1.2(0.71,1.98)$ & $1.2(0.68,2.26)$ \\
\hline
\end{tabular}

\section{References}

1. WHO. Guidelines for Drinking-Water Quality, 3rd ed.; World Health Organization: Geneva, Switzerland, 2008 ; Volume 1.

2. Kebede, A.; Retta, N.; Abuye, C.; Whiting, S.J.; Kassaw, M.; Zeru, T.; Tessema, M.; Kjellevold, M. Dietary fluoride intake and associated skeletal and dental fluorosis in school age children in rural Ethiopian Rift Valley. Int. J. Environ. Res. Publ. Health 2016, 13, 756. [CrossRef]

3. Assefa, G.; Shifera, G.; Melaku, Z.; Haimanot, R.T. Clinical and radiological prevalence of skeletal fluorosis among retired employees of Wonji-Shoa sugar estate in Ethiopia. East Afr. Med. J. 2004, 81, 638-640. [CrossRef]

4. Kravchenko, J.; Rango, T.; Akushevich, I.; Atlaw, B.; McCornick, P.G. The effect of non-fluoride factors on risk of dental fluorosis: Evidence from rural population of the Main Ethiopian Rift. Sci. Total Environ. 2014, 488-489, 595-606. [CrossRef]

5. Melaku, Z.; Assefa, G.; Enqusilassie, F.; Bjorvatn, K.; Tekle-Haimanot, R. Epidemiology of skeletal fluorosis in Wonji Shoa Sugar Estate, Wonji, Ethiopia: A community based survey. Ethiop. Med. J. 2012, 50, 307-313. [PubMed] 
6. Tekle-Haimanot, R.; Haile, G. Chronic alcohol consumption and the development of skeletal fluorosis in a fluoride endemic area of the Ethiopian Rift Valley. J. Water Res. Protect. 2014, 6, 149-155. [CrossRef]

7. Demelash, H.; Beyene, A.; Abebe, Z.; Melese, A. Fluoride concentration in ground water and prevalence of dental fluorosis in Ethiopian Rift Valley: Systematic review and meta-analysis. BMC Publ. Health 2019, 19, 1298. [CrossRef]

8. Wondwossen, F.; Astrom, A.N.; Bjorvatn, K.; Bardsen, A. The relationship between dental caries and dental fluorosis in areas with moderate and high-fluoride drinking water in Ethiopia. Commun. Dent. Oral Epidemiol. 2004, 32, 337-344. [CrossRef] [PubMed]

9. Tandon, V.; Amit, T.; Vikas, S. Fluoride Toxicity; LAP Lambert Academic Publishing: Saarbrücken, Germany, 2015.

10. Dhuna, A.K.; Gu, X.F.; Pascual-Leone, A.; Lee, M. Skeletal fluorosis. An unusual cause of progressive radiculomyelopathy. Spine 1992, 17, 842-844. [CrossRef]

11. McDonagh, M.S.; Whiting, P.F.; Wilson, P.M.; Sutton, A.J.; Chestnutt, I.; Cooper, J.; Misso, K.; Bradley, M.; Treasure, E.; Kleijnen, K. Systematic review of water fluoridation. Br. Med. J. 2000, 32, 855-859. [CrossRef]

12. Shashi, A.; Kumar, M.; Bhardwaj, M. Incidence of skeletal deformities in endemic fluorosis. Trop. Doctor 2008, 38, $231-233$.

13. Wondwossen, F.; Astrøm, A.N.; Bjorvatn, K.; Bårdsen, A. Socio-demographic and behavioural correlates of severe dental fluorosis. Int. J. Paediatr. Dent. 2006, 16, 95-103. [CrossRef] [PubMed]

14. Almebo, A.; Mangasha, H.B.; Ashuro, Z.; Soboksa, N.E.; Kanno, G.G.; Negassa, B.; Mangasha, A.E.; Ayinalem, A.E.; Aregu, M.B. Utilization of community-level fluoride-filtered water and its associated factors in Dugda Woreda of East Shewa Zone, Oromia Region, Ethiopia. Environ. Health Insights 2021, 15, 1-8. [CrossRef]

15. Fawell, J.; Bailey, K.; Chilton, J.; Dahi, E.; Fewtrell, L.; Magara, Y.J. Fluoride in Drinking-Water; IWA Publishing: London, UK, 2006; pp. 1-35.

16. Tekle-Haimanot, R.; Melaku, Z.; Kloos, H.; Reimann, C.; Fantaye, W.; Zerihun, L.; Bjorvatn, K. The geographic distribution of fluoride in surface and groundwater in Ethiopia with an emphasis on the Rift Valley. Sci. Total Environ. 2006, 367, 182-190. [CrossRef]

17. Malde, M.K.; Zerihun, L.; Julshamn, K.; Bjorvatn, K. Fluoride, calcium and magnesium intake in children living in a high-fluoride area in Ethiopia. Intake through food. Int. J. Paediat. Dent. 2004, 14, 167-174. [CrossRef] [PubMed]

18. Teotia, M.; Teotia, S.P.; Singh, K.P. Endemic chronic fluoride toxicity and dietary calcium deficiency interaction syndromes of metabolic bone disease and deformities in India. Ind. J. Pediatr. 1998, 65, 371-381. [CrossRef]

19. Susheela, A.K.; Bhatnagar, M. Reversal of fluoride induced cell injury through elimination of fluoride and consumption of diet rich in essential nutrients and antioxidants. Mol. Cell. Biochem. 2002, 234/235, 335-340. [CrossRef]

20. Kebede, A.; Retta, N.; Abuye, C.; Whiting, S.J.; Kassaw, M.; Zeru, T.; Woldeyohannes, M.; Malde, M.K. Minimizing bioavailability of fluoride through addition of calcium-magnesium citrate or a calcium and magnesium-containing vegetable to the diets of growing rats. Int. J. Biochem. Res. Rev. 2016, 10, 1-8. [CrossRef]

21. Pius, A.; Viswanathan, G. Determination of calcium dose for minimizing fluoride bioavailability in rabbits. Curr. Sci. 2008, 95, 770-773.

22. Tesfaye, B.; Sinclair, K.; Wuehler, S.E.; Moges, T.; De-Regil, L.M.; Dickin, K.L. Applying international guidelines for calcium supplementation to prevent pre-eclampsia: Simulation of recommended dosages suggests risk of excess intake in Ethiopia. Publ. Health Nutr. 2019, 22, 531-541. [CrossRef]

23. Mulualem, D.; Hailu, D.; Tessema, M.; Whiting, S.J. Efficacy of calcium-containing eggshell powder supplementation on urinary fluoride and fluorosis symptoms in women in the Ethiopian Rift Valley. Nutrients 2021, 13, 1052. [CrossRef]

24. 24. FAO; FHI 360. Minimum Dietary Diversity for Women: A Guide for Measurement, FAO: Rome, Italy, 2016.

25. Wu, H.; Gozdzik, A.; Barta, J.L.; Wagner, D.; Cole, D.E.; Vieth, R.; Parra, E.; Whiting, S. The development and evaluation of a food frequency questionnaire used in assessing vitamin D intake in a sample of healthy young Canadian adults of diverse ancestry. Nutr. Res. 2009, 29, 255-261. [CrossRef]

26. EPHI (Ethiopian Public Health Institute). Food Composition Table for Use in Ethiopia; Ethiopian Public Health Institute: Addis Abeba, Ethiopia, 2013.

27. Mesfin, D.J. Exotic Ethiopian Cooking; Ethiopian Cooking Enterprises of Falls Church: Falls Church, VA, USA, 2006.

28. Dean, H.T. Classification of mottled enamel diagnosis. J. Am. Dent. Assoc. 1934, 21, 1421-1426. [CrossRef]

29. Susheela, A.K. Fluorosis in developing countries, remedial measures and approaches. Proc. Ind. Nat. Sci. Acad. USA 2002, 5 , 389-400.

30. Mason, R.L. Regression analysis and problems of multicollinearity. Commun. Statistics 1975, 4, 277-292. [CrossRef]

31. Smith, M.C.; Lantz, E.M.; Smith, H.V. The cause of mottled enamel. Science 1931, 74, 244. [CrossRef]

32. More, C.; Bettembuk, P.; Bhattoa, H.P.; Balogh, A. The effects of pregnancy and lactation on bone mineral density. Osteoporos. Int. 2001, 12, 732-737. [CrossRef]

33. Imdad, A.; Bhutta, Z.A. Effects of calcium supplementation during pregnancy on maternal, fetal and birth outcomes. Paediatr. Perinat. Epidemiol. 2012, 26 (Suppl. 1), 138-152. [CrossRef] [PubMed]

34. Shifera, G.; Tekle Haimanot, R. A Review of the Defluoridation Program of Drinking Water Supplies of an Ethiopian Community. In Proceedings of the Second International Workshop on Fluorosis and Defluoridation of Water, Nazareth, Ethiopia, 19-25 November 1997; International Society for Fluoride Research: Dunedin, New Zealand, 1999. 
35. Dahi, E. Contact Precipitation a Promising Method for Defluoridation of Water. In Proceedings of the Second International Workshop on Fluorosis and Defluoridation of Water, Nazareth, Ethiopia, 19-25 November 1997; International Society for Fluoride Research: Dunedin, New Zealand, 1999.

36. Ahmed, W.; Hamilton, K.A.; Gyawali, P.; Toze, S.; Haas, C.N. Evidence of avian and possum fecal contamination in rainwater tanks as determined by microbial source tracking approaches. Appl. Environ. Microbiol. 2016, 82, 4379-4386. [CrossRef] [PubMed]

37. Butera, A.; Pascadopoli, M.; Gallo, S.; Lelli, M.; Tarterini, F.; Giglia, F.; Scribante, A. SEM/EDS evaluation of the mineral deposition on a polymeric composite resin of a toothpaste containing biomimetic zn-carbonate hydroxyapatite (microRepair ${ }^{\circledR}$ ) in oral environment: A randomized clinical trial. Polymers 2021, 13, 2740. [CrossRef] 